\title{
PENINGKATAN MOTIVASI DAN PRESTASI BELAJAR FIQH DENGAN MODEL COOPERATIVE LEARNING TIPE STAD DI MADRASAH
}

\begin{abstract}
Ma'ruf Yuniarno
ABSTRAK

Penelitian ini bertujuan untuk mengetahui bagaimana cara meningkatkan motivasi dan prestasi siswa melalui model cooperative learning tipe STAD (Student Team Achievement). Penelitian ini merupakan penelitian tindakan kelas (Classroom Action Resarch) dalam pembelajaran Fiqh menggunakan model cooperative learning tipe STAD (Student Team Achievement). Subyek penelitian ini adalah siswa kelas IX A MTs Muhammadiyah Kasihan, Bantul tahun pelajaran 2015-2016. Hasil penelitian ini menunjukkan adanya peningkatan motivasi belajar secara signifikan. Prosentase motivasi belajar siswa pada prasiklus sebesar 26\%, siklus I pertemuan I sebesar 30\%, pertemuan II naik menjadi 59\%. Siklus II pertemuan I naik menjadi $60 \%$ kemudian pada pertemuan II menjadi $78 \%$. Siklus III pertemuan I naik menjadi $79 \%$ dan pada pertemuan II naik menjadi $85 \%$. Prestasi belajar siswa yang diperoleh pada siklus I pertemuan I sebesar $84,2 \%$, pertemuan ke II naik menjadi $88,1 \%$. Namun pada siklus II pertemuan I turun menjadi $85,1 \%$, pertemuan II turun secara signifikan menjadi $62,9 \%$. Siklus III pertemuan I penerapan cooperative learning tipe STAD ditingkatkan kembali sehingga prosentase yang diperoleh naik menjadi $97,8 \%$ dan pada pertemuan II naik menjadi 98,4\%. Penerapan model cooperative learning tipe STAD dapat meningkatkan motivasi dan prestasi dengan melakukan modifikasi dalam hal; penggunaan media yang menarik, pengaturan tempat duduk, dan strategi pengelolaan kelas yang efektif.
\end{abstract}

Kata kunci : Model Pembelajaran Cooperative Learning tipe STAD, motivasi dan prestasi

\section{PENDAHULUAN}

Ketercapaian tujuan pembelajaran tidak lepas dari peran seorang guru. Mulyasa (2013:9) mengatakan bahwa "aspek sikap, nilai, perasaan, motivasi, kepribadian, keteladanan, kebiasaan tidak akan mungkin dapat dihadirkan dalam sebuah pembelajaran kecuali kehadiran seorang guru"

Senada dengan hal tersebut, salah satu peran guru sebagai pelaksana pendidikan yaitu menjadi motivator dalam pembelajaran. Musfah (2012: 42) mengatakan bahwa "guru harus bisa menjadi motivator bagi para muridnya, sehingga potensi mereka berkembang maksimal”.

$$
\text { Realita yang terjadi di MTs }
$$

Muhammadiyah Kasihan motivasi siswa kelas IX A terhadap mata pelajaran fiqh masih rendah. Terbukti melalui hasil observasi masih terdapat siswa yang bermalas-malasan dalam pembelajaran, dari 34 siswa hanya 5 siswa yang aktif menjawab pertanyaan, sedangkan beberapa siswa tidur di kelas dan berbicara dengan teman sebangkunya, sehingga suasana kelas menjadi gaduh dan pembelajaran tidak kondusif. Sikap seperti ini menunjukkan 
74 Ma'ruf Yuniarno, Peningkatan Motivasi Dan Prestasi Belajar Fiqh .....

motivasi siswa tergolong rendah yang dapat mempengaruhi prestasi akademik siswa.

Prestasi akademik yang diperoleh siswa merupakan istilah yang menunjukkan kualifikasi yang diperoleh siswa setelah mengikuti proses pembelajaran dalam suatu program yang telah ditentukan oleh sekolah. Djamarah (2012: 19) mengungkapkan "Prestasi adalah hasil dari sesuatu yang telah dikerjakan, diciptakan, baik secara indivual maupun kelompok".

Data yang menunjukkan rendahnya prestasi akademik adalah :

1. Rata-rata nilai tugas adalah 70 dengan prosentase $58 \%$ siswa berprestasi rendah dan $42 \%$ siswa berprestasi tinggi

2. Rata-rata nilai ulangan harian adalah 79 dengan prosentase $17 \%$ siswa berprestasi rendah dan $83 \%$ siswa berprestasi tinggi, namun prestasi tinggi tersebut juga masih saja ada beberapa siswa yang mencontek teman saat mengerjakan ulangan.

3. Rata-rata nilai ulangan tengah semester adalah 78 dengan prosentase $32 \%$ siswa berprestasi rendah dan $68 \%$ siswa berprestasi tinggi.

Berdasarkan data di atas penting untuk dilakukan penelitian terhadap mata pelajaran Fiqh. Motivasi dan prestasi pada mata pelajaran Fiqh perlu ditingkatkan karena merupakan implementasi Pendidikan Agama Islam dalam kehidupan sehari-hari.
Penelitian ini sangat penting untuk dilakukan karena jika guru mampu menerapkan model pembelajaran cooperative learning tipe STAD dan dapat membangkitkan motivasi siswa terhadap pembelajaran Fiqh, maka siswa akan bersungguh-sungguh dalam belajar tanpa merasa jenuh dan bermalas-malasan. Apabila motivasi belajar tinggi, maka prestasi akademik yang diraih siswa akan meningkat. Penelitian ini dapat menjadi acuan pendidik lain untuk menggunakan model pembelajaran cooperative learning tipe STAD pada saat mengajar di kelas.

Berdasarkan latar belakang masalah tersebut dirumuskan masalah penelitian yakni :

1. Apakah model cooperative learning tipe STAD (Student Teams Achievement Divisions) dapat meningkatkan motivasi belajar siswa pada mata pelajaran Fiqh?

2. Apakah model cooperative learning tipe STAD (Student Teams Achievement Divisions) dapat meningkatkan prestasi belajar siswa pada mata pelajaran Fiqh?

Sedangkan tujuan penelitian ini adalah :

1. Mengidentifikasi model cooperative learning tipe STAD (Student Teams Achievement Divisions) dalam meningkatkan motivasi belajar siswa pada mata pelajaran Fiqh. 
2. Mengkaji model cooperative learning tipe STAD (Student Teams Achievement Divisions) dalam meningkatkan prestasi belajar siswa pada mata pelajaran Fiqh.

Adapun kegunaan penelitian ini secara teoritis maupun praktis adalah:

1. Secara Teoritis

Hasil penelitian ini dapat memperkuat landasan teori pembelajaran model cooperative learning tipe STAD.

2. Secara Praktis

a. Bagi siswa

$\begin{array}{llr}\text { Penelitian ini dapat } & \text { dan } \\ \text { meningkatkan } & \text { motivasi } & \text { dan } \\ \text { prestasi belajar. } & & \end{array}$

b. Bagi guru

Penelitian ini dapat menjadi referensi penggunaan metode cooperative learning tipe STAD untuk meningkatkan kualitas pembelajaran.

c. Bagi sekolah

Penelitian ini dapat menumbuhkembangkan iklim pembelajaran yang berkualitas dan memotivasi guru lain untuk melakukan penelitian tindakan kelas.

d. Bagi peneliti lain

Memberikan wawasan dan informasi bagi penelitian berikutnya berkaitan dengan model pembelajaran cooperative learning tipe STAD (student Teams Achievement Divisions)

\section{METODE PENELITIAN}

\section{A. Jenis Penelitian}

Penelitian ini merupakan penelitian tindakan kelas (classroom action research$C A R)$. Menurut Arikunto, Suhardjono, Supardi (2015: 1-2) penelitian tindakan kelas adalah penelitian yang memaparkan terjadinya sebab akibat dari perlakuan, sekaligus memaparkan apa saja yang terjadi ketika perlakuan diberikan dan memaparkan seluruh proses awal pemberian perlakuan sampai dengan dampak dari perlakuan tersebut.

B. Lokasi Penelitian

Penelitian ini dilaksanakan di MTs Muhammadiyah, dikelurahan Bangunjiwo, kecamatan Kasihan, kabupaten Bantul, Yogyakarta.

\section{Subjek Penelitian}

Pada penelitian tindakan kelas ini (classroom action research) subjek yang akan diteliti yaitu siswa dan siswi kelas IX A, dengan jumlah sebanyak 34 anak. Terdiri dari 21 siswa laki-laki dan 13 siswi perempuan.

\section{Metode Pengumpulan Data}

Penelitian ini menggunakan tiga metode pengumpulan data yaitu observasi, wawancara dan dokumentasi. Adapun metode pengumpulan data tersebut selengkapnya sebagai berikut: 


\section{Observasi}

Observasi ini dilakukan oleh pengamat (kolaborator) yang bertugas mengamati proses pembelajaran dibantu guru mata pelajaran Fiqh (Peneliti). Hal ini dilakukan, untuk mempermudah pengamatan dan menjaga obyektifitas peneliti.

\section{Tes}

Fungsi dari tes yaitu untuk mengukur sejauh mana siswa dapat bekerja sama dengan siswa lain yang merupakan tujuan dari pembelajaran cooperative learning yaitu pembelajaran berbasis sosial. Dalam penelitian ini digunakan instrument tes tertulis untuk mengetahui prestasi siswa pada mata pelajaran Fiqih setiap siklusnya.

\section{Wawancara}

Hal itu dilakukan untuk memperoleh informasi mengenai sekolah dan situasi kelas sebelum dan setelah diterapkannya model pembelajaran cooperative learning tipe STAD.

\section{Dokumentasi}

Dokumentasi digunakan untuk memperkuat data yang diperoleh dari data observasi, tes dan wawancara serta untuk mengetahui data yang terkait dengan sejarah sekolah, jumlah guru, jumlah murid, presensi siswa, kumpulan soal yang dibuat guru, daftar nilai, catatan siswa, pekerjaan tulis siswa dan lain sebagainya.

\section{Definisi Konsep dan Variabel}

Konsep pada penelitian ini dapat dilihat pada gambar dibawah ini:

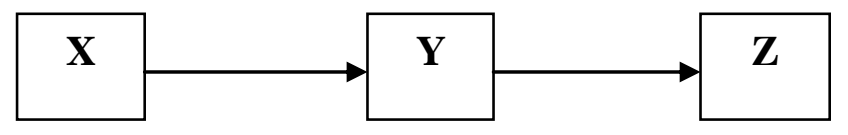

Gambar : Hubungan Tiga Variabel, Sumber dari Noor (2011: 57)

Konsep dari penelitian tindakan kelas ini adalah membuktikan adanya peningkatan motivasi dan prestasi belajar siswa pada mata pelajaran Fiqh melalui model cooperative learning tipe STAD (Student Teams Achievement Divisions) di MTS Muhammadiyah Kasihan Bantul. Sedangkan variabel pada penelitian ini adalah sebagai berikut:

a. Variabel bebas atau yang biasa disebut dengan variabel independen adalah model cooperative learning tipe STAD (Student Teams Achievement Divisions).

Adapun indikator-indikator untuk model cooperative learning tipe STAD (Student Teams Achievement Divisions), adalah sebagai berikut:

1) Menyampaikan tujuan pembelajaran dan memotivasi siswa

2) Penyajian informasi atau penyajian kelas

3) Mengorganisasikan siswa kedalam kelompok belajar

4) Membimbing kelompok untuk bekerja dan belajar

5) Melakukan diskusi antar kelompok

6) Evaluasi serta pemberian penghargaan (Suprijono, 2013: 65). 
b. Variabel terikat atau yang biasa disebut dengan variabel dependen yaitu Motivasi Belajar (Y) dan Prestasi Belajar (Z)

1) Adapun indikator untuk motivasi belajar adalah sebagai berikut :

a). Selalu mencatat penjelasan guru

b). Mendengarkan dan memperhatikan saat guru menerangkan

c). Berani bertanya pada guru d). Berani mengemukakan pendapat/ide

e). Menjawab pertanyaan guru

f). Tekun mengerjakan tugas dari guru

g). Mengerjakan tugas sesuai perintah

h). Antusias saat pembelajaran berlangsung

i). Berpartisipasi saat diskusi berlangsung

j). Disiplin saat pembelajaran berlangsung

Tabel : Skor Instrumen

\begin{tabular}{|c|l|l|}
\hline Skor & \multicolumn{1}{|c|}{ Predikat } & \multicolumn{1}{c|}{ Persyaratan } \\
\hline 4 & Motivasi Sangat Tinggi & Memenuhi 10 Syarat \\
\hline 3 & Motivasi Tinggi & Memenuhi 6 Syarat \\
\hline 2 & Motivasi Kurang & Memenuhi 2 Syarat \\
\hline 1 & Tidak Termotivasi & Tidak Ada Syarat yang Terpenuhi \\
\hline
\end{tabular}

2) Indikator prestasi belajar dapat dilihat dari skor yang diperolehnya. Jika skor dibawah KKM yaitu 75 maka siswa tersebut belum tuntas mengikuti pembelajaran dan prestasinya masih rendah. Sedangkan siswa yang mendapat lebih dari 75 misalnya 95 maka siswa tersebut sudah tuntas dalam mengikuti pembelajaran serta prestasi belajar yang diperoleh sudah tergolong bagus karena skor yang diperoleh sudah bagus.

6. Analisis Data

Teknik analisis data yang digunakan dalam penelitian ini adalah teknik deskriptif kualitatif yakni:

\section{Analisis Data Observasi}

Data hasil observasi dianalisis dengan menggambar hambatan yang muncul dalam pelaksanaan

pembelajaran

mendeskripsikan aktivitas siswa dalam kegiatan pembelajaran serta respon siswa terhadap pembelajaran. Sedangkan untuk menilai bagaimana aktivitas siswa, skor perolehan dibuat persentase kemudian dikualifikasikan untuk mengukur sejauh mana aktivitas belajar yang dicapai dalam pembelajaran. Hasil analisis data observasi ini kemudian disajikan secara deskriptif. Prosentase motivasi belajar dihitung dengan rumus:

$$
\frac{\text { Nilai rata }- \text { rata } X 100 \%}{\text { Nilai Maksimal }}
$$

Analisis kualititaf, adapun langkah-langkahnya:

a. Pengumpulan data

Pada penelitian ini mengumpulkan data untuk membuat pemecahan masalah. 
Adapun cara pengumpulan data adalah semua data dari hasil observasi, wawancara dan dokumentasi dikumpulkan kemudian dianalisis.

b. Penyajian data

Hasil analisis data, kemudian data disajikan kedalam tabel, grafik dengan menggunakan rumus-rumus penelitian kuantitatif.

c. Reduksi data

Reduksi data adalah salah satu teknik yang digunakan untuk mengumpulkan datadata yang masih mentah yang didapatkan dari hasil observasi aktivitas di lapangan (Nurwidayati, 2012: 41).

d. Triangulasi Data

Tringulasi adalah salah satu cara yang dilakukan untuk menguji keabsahan data dari hasil analisis hasil penelitian. Teknik tringulasi merupakan pemeriksaan keabsahan data yang memanfaatkan sesuatu yang lain. Data itu untuk keperluan pengecekan atau sebagai pembanding terhadap data itu.

e. Kesimpulan sementara Kesimpulan yang diambil sebelum meneliti secara mendalam. Kesimpulan ini masih dapat berubah seiring dengan penelitian yang dilakukan.

2. Analisisi data wawancara

Analisis wawancara digunakan untuk merencanakan beberapa tindakan selanjutnya yang telah dievaluasi terlebih dahulu dengan tujuan untuk meningkatkan motivasi dan prestasi belajar siswa terhadap pembelajaran Fiqh.

\section{HASIL PENELITIAN}

1. Prasiklus

Sebelum memasuki Siklus I terlebih dahulu peneliti melakukan penelitian awal yang disebut dengan prasiklus. Pada prasiklus ini peneliti menggunakan metode konvensional yaitu ceramah.

Presentase motivasi belajar siswa pada pembelajaran Fiqh adalah 26\%. Berdasarkan daftar nilai dan analisis hasil evaluasi MTs Muhammadiyah Kasihan semester gasal tahun pelajaran 2015/2016 adalah sebagai berikut: rata-rata nilai tugas adalah 70 jika dipresentasikan menjadi $58 \%$ siswa berprestasi rendah dan $42 \%$ siswa berprestasi tinggi, ulangan harian rata-rata 79 jika dipresentasekan sebanyak $17 \%$ siswa berprestasi rendah dan $83 \%$ siswa berprestasi tinggi.

2. Siklus I 


\section{a. Pertemuan I}

Perencanaan yang dilakukan dengan pertama, membuat RPP dan alat pembelajaran. Kedua mempersiapkan lembar observasi atau lembar pengamatan.

Pelaksanaan Tindakan dilakukan dengan mengajarkan materi jual beli dengan durasi waktu 2X40 menit. Langkah-langkah pembelajaran yang dilakukan adalah sebagai berikut:

a) Kegiatan awal yang diawali dengan apersepsi dan menjelaskan tujuan pembelajaran

b) Kegiatan inti dilakukan pertama; Pembagian kelompok secara heterogen, kedua; Penjelasan guru tentang materi jual beli, ketiga; siswa mengerjakan LKS dengan cara diskusi, keempat; presentasi dari masing-masing keolompok.

c) Kegiatan akhir siswa menyimpulkan hasil diskusi klasikal (guru membantu memfasilitasi), mengerjakan tugas individu berupa tes, memajang hasil tugas kelompok serta refleksi terhadap proses pembelajaran yang telah dilakukan, memberikan hadiah kepada siswa yang aktif dalam pembelajaran.

Hasil pengamatan pada pertemuan I adalah guru sudah menggunakan model pembelajaran cooperative learning tipe STAD yang identik dengan pengelompokan siswa. Motivasi siswa pada pertemuan I ini sebesar 30
$\%$ sedangkan prestasi belajar yang diraih sebesar $84,2 \%$.

\section{b. Pertemuan ke II}

Perencanaan pada pertemuan II dilakukan seperti pada pertemuan pertama serta memberikan modifikasi dengan menggunakan media berupa kertas yang didalamnya terdapat lembar pengamatan siswa.

Pelaksanaan Tindakan dengan mengajarkan materi Qiradh melalui langkah

a) Kegiatan awal dilakukan dengan melakukan apersepsi

b) Kegiatan inti melakukan proses; pembagian kelompok secara heterogen. Selanjutnya siswa mendengarkan, menyimak dan mencatat penjelasan guru tentang materi yang dibahas guru. Siswa mengambil tugas kelompok yang diberikan guru berupa LKS. Siswa mendiskusikan tugas dalam LKS untuk mendapat kesepakatan bersama. Melaporkan hasil diskusi kelompok secara klasikal.

c) Pada kegiatan akhir siswa menyimpulkan hasil diskusi, siswa mengerjakan tugas individu berupa tes, memajang hasil tugas kelompok serta refleksidan memberikan reward pada siswa yang aktif dan berprestasi.

Hasil pengamatan pada pertemuan II adalah guru sudah menggunakan model pembelajaran cooperative learning tipe STAD. 
80 Ma'ruf Yuniarno, Peningkatan Motivasi Dan Prestasi Belajar Fiqh .....

Motivasi siswa pada pertemuan II ini sebesar $59 \%$ sedangkan prestasi belajar yang diraih sebesar $88,1 \%$.

\section{c. Refleksi Siklus I}

Berdasarkan pengamatan siklus I pertemuan pertama dan kedua dapat disimpulkan bahwa prestasi belajar siswa kelas IX A dengan materi jual beli dan qirad telah mengalami peningkatan. Peningkatan tersebut belum signifikan, maka dari itu perlu dilanjutkan pada siklus ke II. Refleksi siklus I ini akan digunakan untuk meningkatkan pembelajaran pada siklus ke II.

\section{Siklus II}

\section{a. Pertemuan I}

Perencanaan pada siklus II pertemuan I ini adalah seperti pada siklus I dengan modifikasi penambahan media pembelajaran menggunakan slide presentasi power point, menyajikan video pendek berkaitan dengan materi dan mengubah design kelas menjadi leter $\mathrm{U}$.

Pelaksanaan Tindakan dilakukan seperti pada siklus I dengan modifikasi sesuai perencanaan siklus II yang membahas materi tentang qirad.

Berdasarkan pengamatan pertemuan I siklus II ini diperoleh data motivasi siswa sebesar $60 \%$ sedangkan prestasi belajar yang diraih sebesar $85,1 \%$.

\section{b. Pertemuan II}

Perencanaan pada siklus II pertemuan II ini adalah dengan modifikasi seperti pada siklus II pertemuan I.

Pelaksanaan tindakan dilakukan seperti pada siklus II pertemuan I dengan modifikasi dengan materi tentang jual beli.

Berdasarkan pengamatan, pertemuan II siklus II ini diperoleh data motivasi siswa sebesar sebesar $78 \%$ sedangkan prestasi belajar yang diraih siswa sebesar $62,9 \%$.

c. Refleksi Siklus II

Berdasarkan pengamatan siklus II pertemuan I dan II dapat disimpulkan bahwa prestasi belajar siswa kelas IX A dengan materi Jual beli, Qirad, Riba telah mengalami penurunan sedangkan motivasi belajar siswa tetap mengalami kenaikan. Refleksi siklus II ini akan digunakan untuk meningkatkan pembelajaran pada siklus ke III

\section{Siklus III}

a. Pertemuan I

Perencanaan pertemuan ini peneliti telah mempersiapkan perangkatperangkat perbaikan dari siklus II, yaitu: RPP yang lebih terperinci langkah dan waktu pelaksanaannya, media dan strategi pengelolaan tempat duduk serta variasi soal tes yang 
dibuat lebih menyenangkan dengan model teka-teki silang.

Pelaksanaan Tindakan dilakukan seperti pada siklus II pertemuan II dengan modifikasi dengan materi pinjam meminjam dan utang-piutang.

Hasil pengamatan pada pertemuan I ini adalah presentase motivasi belajar siswa terjadi kenaikan yaitu menjadi $79 \%$ sedangkan prestasi belajar siswa mengalami kenaikan yang signifikan menjadi $97,8 \%$. Hal itu menandakan siswa semakin termotivasi dalam pembelajaran fiqh, sehingga prestasi belajar yang diraih meningkat.

\section{b. Pertemuan II}

Perencanaan pertemuan ini peneliti telah mempersiapkan perangkatperangkat perbaikan dari siklus III pertemuan I, khususnya pada pemberian ice breaking pada saat kondisi motivasi siswa mulai menurun.

Pelaksanaan Tindakan sesuai dengan perencanaan dengan menerapkan modifikasi penerapan ice breaking dalam pembelajaran materi tentang muamalah di luar jual beli (upah, jaminan dan gadai)

Hasil pengamatan pada pertemuan II ini adalah presentase motivasi belajar siswa terjadi kenaikan yaitu menjadi
85\% sedangkan prestasi belajar siswa mengalami kenaikan yang signifikan menjadi $98,4 \%$. Hal itu menandakan siswa semakin termotivasi dalam pembelajaran fiqh, sehingga prestasi belajar yang diraih meningkat.

\section{c. Refleksi Siklus III}

Berdasarkan pengamatan siklus III pertemuan I dan II dapat disimpulkan bahwa motivasi dan prestasi belajar siswa kelas IX A dengan materi muamalah di luar jual beli telah mengalami kenaikan.

\section{PEMBAHASAN}

Berdasarkan hasil analisis setiap siklus, dapat di perbandingan antar siklus dalam satu grafik sebagai berikut:

a. Motivasi Belajar

Penelitian tindakan kelas ini terdiri dari tiga siklus yang berfungsi meningkatkan motivasi belajar siswa pada mata pelajaran Fiqh di kelas IX A dengan menggunakan model cooperative learning tipe STAD. Presentase motivasi belajar siswa mengalami peningkatan pada setiap siklus Hal tersebut digambarkan pada grafik dibawah ini, yaitu:

Grafik : Persentase motivasi belajar siswa pada masing-masing siklus dan pertemuan 


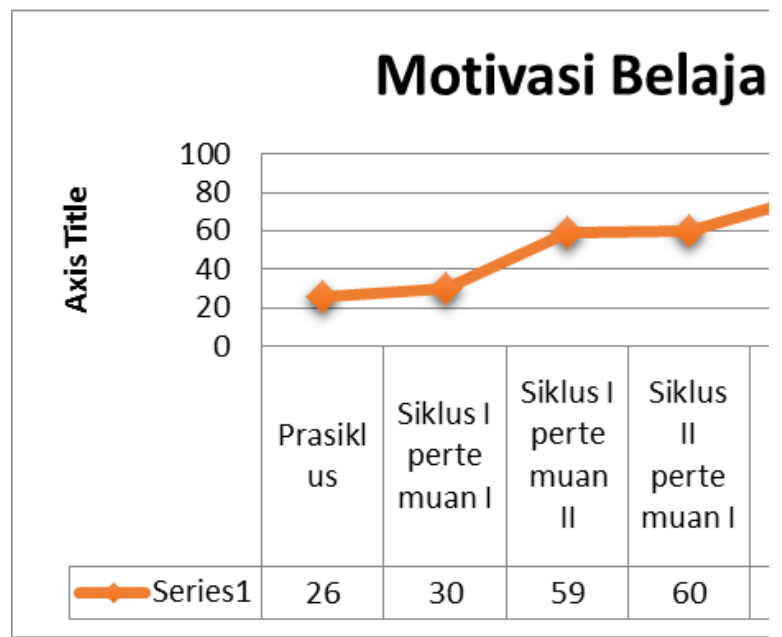

Grafik tersebut menunjukkan motivasi belajar siswa semakin meningkat. Prasiklus menunjukkan presentase motivasi sebesar $26 \%$. Pada prasiklus presentase motivasi siswa rendah sehingga perlu ditingkatkan padasiklus I. Siklus I pertemuan I menunjukkan presentase sebesar 30\%, dilanjutkan pada pertemuan ke II motivasi belajar siswa naik menjadi $59 \%$. Siklus I, siswa mulai termotivasi pada pembelajaran fiqh yang dilaksanakan meskipun masih ada beberapa siswa bermotivasi rendah bahkan belum termotivasi.

Siklus II pertemuan I motivasi belajar siswa mengalami peningkatan dari siklus I, menjadi $60 \%$, kemudian pada pertemuan ke II menigkat menjadi 78\%. Pada siklus II ini model pembelajaran yang digunakan dikolaborasikan dengan sarana dan prasarana yang ada yaitu dengan memakai slide powert point dan menampilkan video pendek pada awal pembelajaran, sehingga siswa tertarik dengan materi yang dipelajari. Banyak siswa yang antusias, aktif dan memperhatikan saat pembelajaran berlangsung.

Kemudian dilanjutkan pada siklus III pertemuan I, presentase motivasi belajar siswa meningkat dari siklus sebelumnya menjadi 79\%. Selanjutnya pada pertemuan II presentase motivasi belajar siswa meningkat menjadi $85 \%$. Pada siklus III ini masih sama dengan siklus II yaitu model pembelajaran yang dipakai dikolaborasikan dengan sarana dan prasarana yang ada, memberikan video pendek di awal pembelajaran serta memberikan ice breaking agar siswa tidak jenuh dengan pelajaran.

Hasil akhir dari pembelajaran dengan menggunakan model cooperative learning tipe STAD dapat meningkatkan motivasi belajar siswa pada mata pelajaran fiqh.

b. Prestasi Belajar Siswa

Penelitian tindakan kelas ini dilakukan selain meningkatkan motivasi belajar juga meningatkan prestasi belajar siswa yang berlangsung di kelas menjadi lebih baik. Hasil presentase masing-masing pertemuan yang terdapat dalam siklus dapat dilihat dibawah ini, yaitu:

Grafik: Persentase prestasi belajar siswa pada masing-masing siklus dan pertemuan

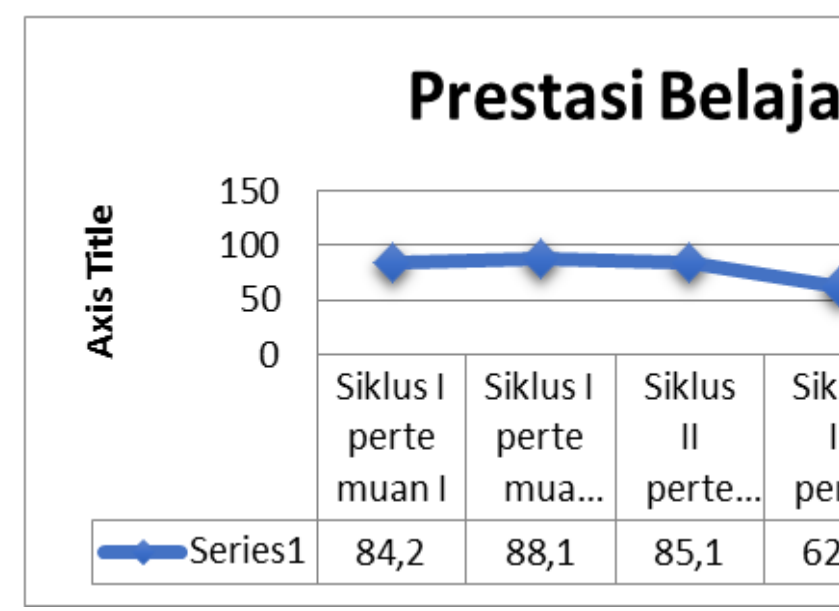

Grafik diatas menunjukkan prestasi belajar siswa pada siklus I pertemuan I sebesar 
$84,2 \%$, dilanjutkan pada pertemuan ke II prestasi belajar siswa naik menjadi $88,1 \%$. Pada siklus I ini siswa dapat menyelesaikan tugas dengan baik sehingga prestasi yang diraih tinggi. Meskipun presentase secara keseluruhan tinggi, namun masih terdapat beberapa siswa yang mendapat nilai di bawah KKM yaitu sebanyak 6 orang.

Siklus II pertemuan I prestasi belajar siswa mengalami penurunan dari siklus I, menjadi $85,1 \%$, kemudian pada pertemuan ke II mnurun secara signifikan menjadi $62,9 \%$. Pada siklus II ini siswa mengalami kesulitan dalam mengerjakan tugas sehingga prestasi belajar yang diraih menjadi menurun, hal itu terbukti 25 siswa yang mendapatkan nilai di bawah KKM.

Kemudian dilanjutkan pada siklus III pertemuan I, presentase prestasi belajar siswa meningkat secara signifikan dari siklus sebelumnya menjadi $97,8 \%$. Selanjutnya pada pertemuan II presentase motivasi belajar siswa menurun menjadi $98,4 \%$.

Berdasarkan hasil diatas model cooperative learning tipe STAD dapat meningkatkan prestasi belajar siswa pada mata pelajaran Fiqh. Dengan catatan setiap pertemuan dalam satu siklus harus memiliki berbagai modifikasi agar siswa memiliki ketertarikan. Modifikasi dapat berupa perubahan tata ruang kelas, posisi duduk, media dan alat pembelajaran, instrumen tes bahkan penggunaan ice breaking untuk menghindarkan siswa dari kejenuhan. Jadi kata kunci signifikansi keberhasilan peningkatan motivasi dan prestasi siswa dibutuhkan sentuhan kreatifitas guru terhadap penerapan metode Cooperative Learning Tipe STAD.

\section{Simpulan}

Berdasarkan data dan analisis penelitian dari bab I sampai bab IV mengenai peningkatan motivasi dan prestasi belajar siswa pada mata pelajaran Fiqh melalui model cooperative learning tipe STAD (Student Teams Achievement Divisions) di MTs Muhammadiyah Kasihan Bantul yang dilakukan pada siswa/i kelas IX A, diperoleh kesimpulan sebagai berikut:

1. Model cooperative learning tipe STAD dapat meningkatkan motivasi belajar siswa pada mata pelajaran Fiqh. Peningkatan tersebut dapat dilihat dari perolehan presentase masing-masing siklus. Presentase motivasi belajar siswa pada prasiklus sebesar 26\%, siklus I pertemuan I sebesar 30\%, pertemuan II naik menjadi $59 \%$. Siklus II pertemuan I naik menjadi $60 \%$ kemudian pada pertemuan II menjadi $78 \%$ sedangkan pada siklus III pertemuan I naik menjadi $79 \%$ dan pada pertemuan II naik menjadi $85 \%$.

2. Model cooperative learning tipe STAD dapat meningkatkan prestasi belajar siswa pada mata pelajaran fiqh. Peningkatan tersebut dilihat dari presentase masing-masing siklus. Prestasi belajar siswa yang 
84 Ma'ruf Yuniarno, Peningkatan Motivasi Dan Prestasi Belajar Fiqh .....

diperoleh pada siklus I pertemuan I sebesar $84,2 \%$, pertemuan ke II naik menjadi $88,1 \%$. Namun pada siklus II pertemuan I turun menjadi $85,1 \%$, pertemuan II turun secara signifikan menjadi 62,9\%. Siklus III pertemuan I penerapan cooperative learning tipe STAD ditingkatkan kembali sehingga presentase yang diperoleh naik menjadi $97,8 \%$ dan pada pertemuan II naik menjadi $98,4 \%$.

\section{Daftar Pustaka}

Arikunto, Suharsimi, Suhardjono dan Supardi. 2015. Penelitian Tindakan Kelas. Jakarta: Bumi Aksara.

Djamarah, Syaiful Bahri. 2012. Prestasi Belajar dan Kompetensi Guru. Surabaya: Usaha Nasional.

Mulyasa, E. 2013. Uji Kompetensi dan Penilaian Kinerja Guru. Bandung: Remaja Rosdakarya.

Musfah, Jejen. 2012. Peningkatan Kompetensi Guru. Jakarta: Kencana.

Noor, Juliansyah. 2011. Metodologi Penelitian. Jakarta: Kencana

Nurwidayati, Putri. 2012. Upaya Meningkatkan Minat Belajar Matematika Pada Siswa Kelas Dengan Menggunakan Alat Peraga Di MI Makukuhan Krajan Temangguang. Yogyakarta : Skripsi Universitas Islam Negeri Sunan Kalijaga.
Slavin, Robert E. 2015. Cooperative Learning Teori, Riset dan Praktik. Bandung: Nusa Media.

Suprijono, Agus. 2013. Cooperative Learning Teori Dan Aplikasi PAIKEM. Yogyakarta: Pustaka Pelajar.

Syaodih, Nana. 2012. Metode Penelitian Pendidikan : Bandung, Remaja Rosdakarya. 